\section{CULBPT-A46 and CULBPT-A48 Series of Late Blight Resistant Processing Tomato Breeding Lines}

\author{
Min-Jea Kim ${ }^{1}$ and Martha A. Mutschler ${ }^{2}$ \\ Department of Plant Breeding and Genetics, Cornell University, 303 Bradfield \\ Hall, Ithaca, NY 14853
}

Additional index words. Lycopersicon esculentum, Phytophthora infestans, disease resistance

\section{Origin}

Late blight is an important disease of tomato foliage, stem and fruit caused by Phytophthora infestans (Mont.) de Bary. The first late blight resistant genes transferred to tomato [Solanum lycopericum L. (syn. Lycopersicon esculentum Mill.)] are $P h-1$ and $P h-2$ (Gallegly, 1960; Peirce, 1970, 1971). $P h-1$ is a single dominant resistance gene derived from Solanum pimpinellifolium L. [syn. Lycopersicon pimpinellifolium (L.) Mill.]. $\mathrm{Ph}-2$ is a single incompletely dominant gene also derived from S. pimpinellifolium. $P h-1$ and $P h-2$ were both rapidly overcome due to their race specificity (Conover and Walter, 1952, 1953; Gallegly, 1952; Goodwin et al., 1995). Neither $P h-1$ nor $P h-2$ was used widely in tomato breeding, and varieties remained susceptible to late blight.

Another source of late blight resistance was discovered by L. Black and P. Hanson (Asian Vegetable Research and Development Center, 1994). This resistance was found in S. pimpinellifolium L3708 (a.k.a. LA1269 C. M. Rick Tomato Genetics Resource Center, Davis, Calif.; USDA accession NSL116890 and PI365957). This accession possesses the $P h-3$ resistance gene, which is located near the bottom of chromosome 9 (Chunwongse et al., 2002). Tomato lines bred using L 3708 possess $P h-3$, as well as additional genes that interact with $P h-3$ to protect the plant against a wider range of isolates of the $P$. infestans than $P h-3$ alone (Kim and Mutschler, 2005a, 2005b).

A series of late blight resistant processing

Received for publication 26 Sept. 2005. Accepted for publication 16 Nov. 2005. We thank PeterHanson and Lowell Black for generously sharing the resistance source L3708. We thank Randy Gardner for providing resistant freshmarket $\mathrm{BC}_{1} \mathrm{~F}_{2}$ cuttings and discussion over the course of this work. We thank William Fry for providing Phytophthora infestans isolates and for his advice on their culture. We thank Ira Stein and Dawn Adams of Campbell's Seeds (Campbell Research \& Development, 28605 County Road 104, Davis, CA 95616) and Casey Garvey and Chuck Fleck of ConAgra Foods (ConAgra Foods, 2121 2nd Street, \#B-102, Davis, CA 95616), and their companies for performing the field trials in California and Mexico. This project was supported by funds from the California League of Food Processors and the USDA HATCH project 149484

${ }^{1}$ Current address: Division of Environmental and Life Sciences, Seoul Women's University, Seoul 139-774, Korea.

${ }^{2}$ To whom reprint requests should be addressed; e-mailmam13@cornell.edu. tomato lines, including the CULBPT-A46 and CULBPT-A48 lines being released, was developed using the $P h-3$ source of resistance (Kim and Mutschler, 2005b). The ultimate source of the late blight resistance used in developing these late blight resistant lines was S. pimpinellifolium L3708. However the start of the breeding process for the CULBPT-A46 and CULBPT-A48 sets of lines were rooted cuttings of late blight-resistant selections from a BC ${ }_{1} \mathrm{~F}_{2}$ population ['NC215E' $\times\left({ }^{\prime} \mathrm{NC} 215 \mathrm{E}\right.$ ' $\times$ S. pimpinellifolium accession L3708)] provided by Randy Gardner of North Carolina State University. ' $\mathrm{NC} 215 \mathrm{E}$ ' is a fresh market tomato line that has a large determinant vine and possesses the $V e$ and $I 2$ genes conditioning resistance to Verticillium dahliae Kleb race 1 and races 1 and 2 of Fusarium oxysporum f.sp. lycopersici (Sacc.) Snyd. and Hans., respectively (R. Gardner, personal communication).

Two different processing tomato hybrids with contrasting characteristics were used as backcross parents in the transfer of the late blight resistance to processing tomato. This approach provided genetic variability for horticultural characteristics in breeding these lines. The processing tomato hybrids used for first and second backcrosses in the pedigree of the CULBPT-A46 sister lines (Fig. 1) were processing tomato.
'Orsetti 3155' (a.k.a. 'BOS 3155' and 'Halley 3155', Orsetti Seed Co., Inc., Hollister, Calif.), and 'Hypeel 45' (Seminis Inc., Oxnard, Calif.). Both of these hybrids possess the Ve and $I 2$ resistance genes.

The processing tomato hybrids used for the first and second backcrosses in the pedigree of the CULBPT-A48 sister lines (Fig. 2) were 'Heinz 8892' (Heinzseed, Division of H.J. Heinz Co., Stockton Calif.), and 'Hypeel 303' (Seminis Inc.), respectively. Both of these hybrids possess the $V e$ and $I 2$ resistance genes as well as $M i$, which provides resistance to root knotnematode (Meloidogyne spp.). In addition, 'Hypeel 303' has the Pto gene conditioning resistance to bacterial speck (Pseudomonas syringae pv. tomato Okabe).

The $P$. infestans isolates US-17 (970001) and US-7 (940486 and 940330) from William Fry (Dept. of Plant Pathology, Cornell University) were used for disease screens in development of these lines. US-7 is an older isolate that was dominant throughout the U.S., but is largely replaced by newer isolates. US-17 is a more recent isolate found in the southeastern U.S. and up the eastern coast to New Jersey and New York (Fry and Goodwin, 1997). Methods for maintaining pathogens and screening for resistance are in Kim and Mutschler (2005b).

\section{Description}

Disease resistance of CULBPT-A46 and $C U L B P T-A 48$ lines. The lines created in the late blight breeding program were resistant to US-7 and US-17, the isolates used in testing during the breeding process. The lines were then tested using the additional $P$. infestans isolates US-11 (from California), DR4B (from the Dominican Republic), and NC-1 (from North Carolina). Results indicated that all of the tomato lines selected for late blight resistance using US-7 and US-17 were also

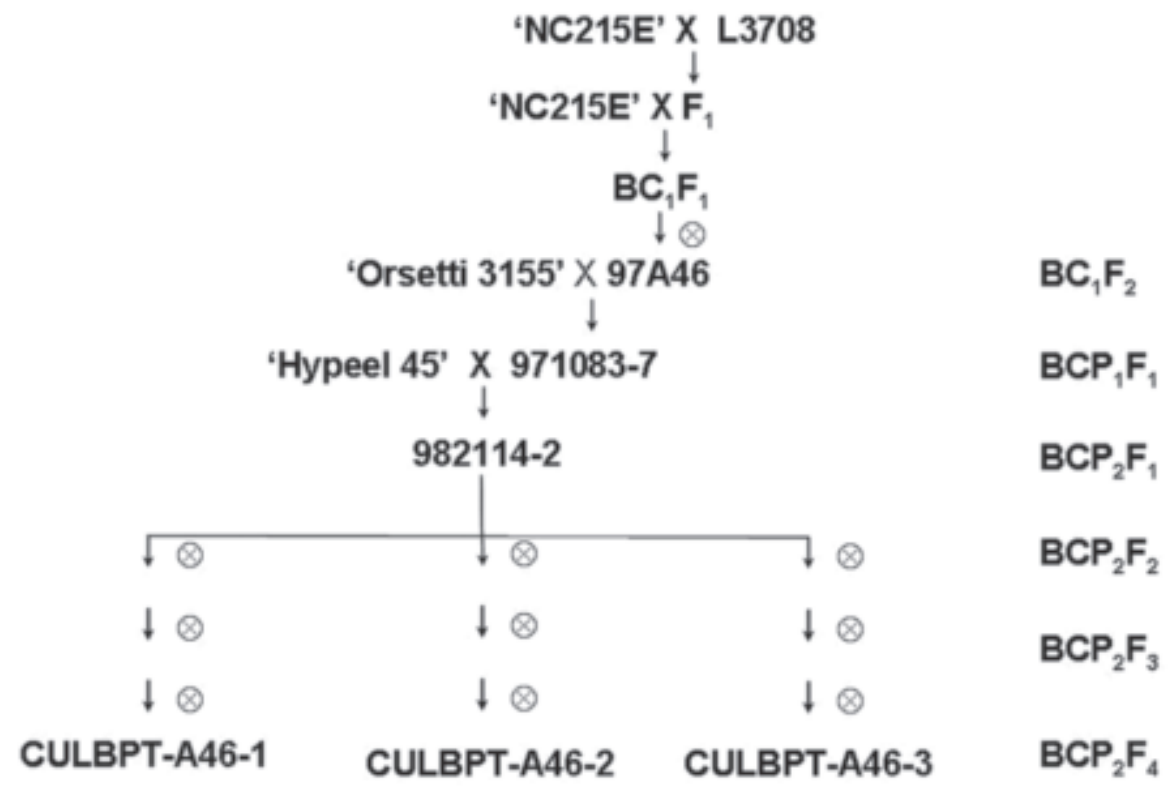

Fig. 1. Pedigree of the 'CULBPT-A46' series of late blight resistant processing tomato, in which $\mathrm{BC}_{1} \mathrm{~F}_{1}$ was first backcross to freshmarket tomato, and BCP generations are generations of backcrossing to 


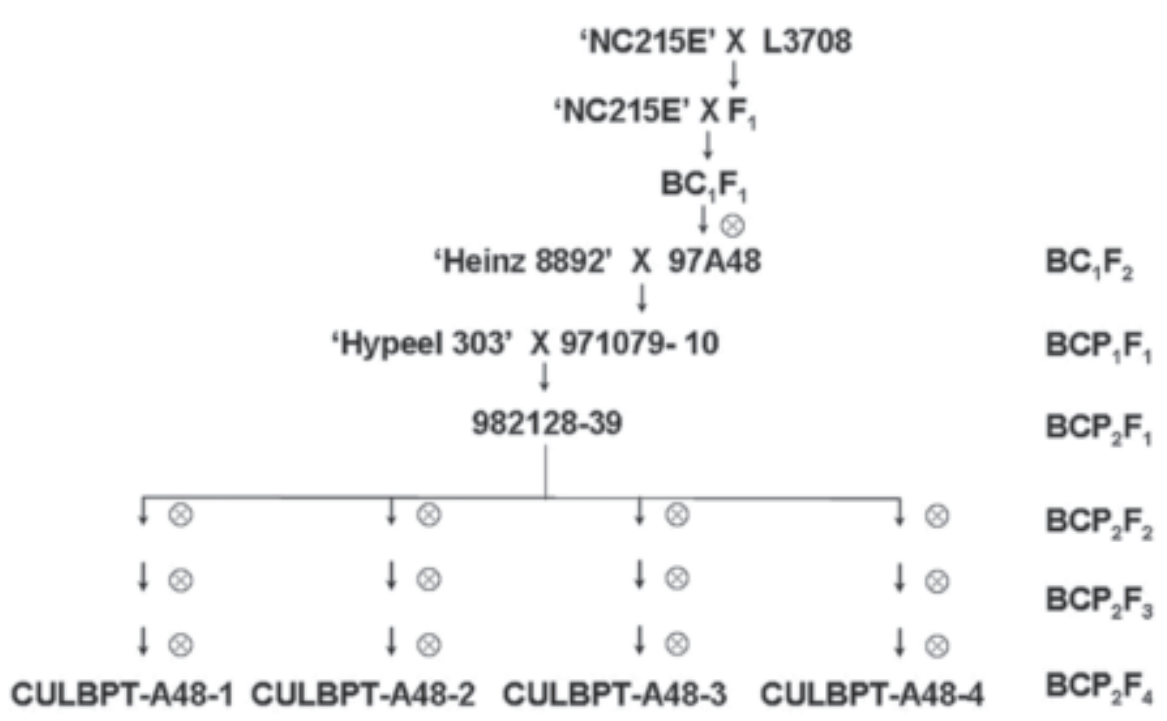

Fig. 2. Pedigree of the 'CULBPT-A48' series of late blight resistant processing tomato, in which $\mathrm{BC}_{1} \mathrm{~F}_{1}$ was first backcross to freshmarket tomato, and BCP generations are generations of backcrossing to processing tomato.

resistant fully to US-11, DR4B and NC-1 (Kim and Mutschler, 2005 a, 2005b). Hybrids heterozygous for the resistance were created by crossing resistant lines with typical late blight susceptible tomato inbreds. In screening these hybrids with the same $P$. infestans isolates, the heterozygous hybrids were nearly as resistant as the homozygous lines against US-11 and DR4B, but were less resistant or nearly susceptible to the other isolates (Kim and Mutschler, 2005a). Therefore the most reliable use of this form of resistance would be in lines or hybrids homozygous for the resistance.

A winter and spring late blight trial was also performed in 2001 in Los Mochis Mexico under the supervision of Ira Stein, who was then with Campbell's Seeds (Campbell Research \& Development, Davis, Calif.). The winter trial contained control lines and 23 late blight resistant breeding lines, including the CULBPT-A46 and CULBPT-A48 sister lines. Since this trial relied on natural infection rather chuk et al (1998) were used to screen for Ve. 'CULBPT-A46-1', 'CULBPT-A46-2' and 'CULBPT-A46-3' are all homozygous for $V e$, $\mathrm{I} 2$ and $\mathrm{Mi}$. 'CULBPT-A-48-2' and 'CULBPTA48-4' are both homozygous for $V e, I 2$, and Pto. 'CULBPT-A-48-1' is homozygous for Ve and $I 2$, and 'CULBPT-A48-3' is homozygous for $I 2$, and Pto.

Horticultural evaluations in California. The horticultural and fruit quality of a series of late blight resistant lines and controls was tested in trials in Woodland, Calif., hosted by Hunts/ConAgra and Campbell's Seeds. Both trials used a randomized complete-block design with three replications. Cooperators used their company's proprietary protocols for variety evaluation. The processing tomato varieties used as controls were the commercial hybrids, 'Orsetti 3155', 'Hypeel 45', and 'Hypeel 303', and the experimental hybrid 'CXD 207'(Campbell's Seeds). 'Orsetti 3155' and 'Hypeel 45 'were parents in the pedigree of the CULBPT-A46 lines, and 'Hypeel 303' was a parent in the pedigree of CULBPT-A48 lines.

The results of these trials indicate that, in addition to carrying strong resistance to late blight, most of these seven lines were not significantly different than current hybrid controls for most of the characteristics recorded (Tables 1 and 2). Fruit firmness, color, viscosity, fruit solids (as measured by \%Brix, TS, and NTSS), and acidity, as measured by $\mathrm{pH}$, of these lines were all in the range of those characteristics of the hybrid varieties used as controls. The CULBPT-A46 lines are jointed and therefore had some stem adhesion, also seen in the jointed control, CXD 207. The CULBPT-A46 lines also tend to be early in maturity, and have slightly smaller fruit size. The CULBPT-A48 lines are jointless, and had low stem adhesion characteristic also observed in the jointless control hybrid 'Hypeel 303'. The CULBPT-A48 lines have very large vines with very good cover, large fruit, and tend to have later maturity in Ithaca. There is a tendency in these trials for some of the CULBPT-A46

Table 1. Test of horticultural quality characteristics performed by Hunt's Co. in Woodland Calif., 2000 of commercial controls and CULBPT-A46 and CULBPTA48 lines.

\begin{tabular}{|c|c|c|c|c|c|c|c|c|c|c|}
\hline Cultivar & $\begin{array}{l}\text { Fruit } \\
\text { wt/g }\end{array}$ & $\mathrm{pH}$ & $\begin{array}{c}\text { Raw } \\
\text { \%Brix }\end{array}$ & Viscosity ${ }^{y}$ & $\begin{array}{l}\text { Vine } \\
\text { cover }^{x}\end{array}$ & $\begin{array}{l}\text { Vine } \\
\text { sizew }\end{array}$ & $\begin{array}{c}\text { Fruit } \\
\text { firmness }^{v}\end{array}$ & Yield $^{u}$ & Concn ${ }^{t}$ & Maturity \\
\hline BOS3155 & 69.6 & 4.0 & 5.1 & 38.3 & 3.0 & 6.7 & 4.7 & 5.0 & 5.3 & 83.3 \\
\hline Hypeel45 & 72.7 & 4.0 & 5.3 & 34.3 & 4.0 & 5.0 & 3.0 & 4.3 & 5.0 & 96.7 \\
\hline CULBPT-A46-1 & 57.4 & 4.3 & 5.7 & 52.3 & 5.0 & 7.3 & 4.7 & 4.7 & 4.3 & 76.7 \\
\hline CULBPT-A46-2 & 55.8 & 4.0 & 5.0 & 44.4 & 5.0 & 6.0 & 4.3 & 4.0 & 3.0 & 78.3 \\
\hline CULBPT-A46-3 & 56.0 & 4.3 & 5.6 & 49.2 & 4.7 & 7.3 & 4.7 & 3.0 & 4.3 & 80.0 \\
\hline CULBPT-A48-3 & 44.3 & 4.4 & 6.2 & 37.4 & 4.0 & 6.3 & 3.3 & 4.0 & 5.0 & 83.3 \\
\hline CULBPT-A48-4 & 57.6 & 4.5 & 5.8 & 31.4 & 4.0 & 5.3 & 3.3 & 4.0 & 4.3 & 78.3 \\
\hline $\operatorname{LSD}^{r}$ & 10.3 & 0.4 & 0.6 & 4.7 & 1.2 & 0.8 & 1.1 & 1.5 & 1.0 & 8.3 \\
\hline
\end{tabular}

${ }^{2}$ Raw Brix $=$ percent soluble solids.

'Measured by Hunt's standard method.

${ }^{\mathrm{x}}$ Scale of $1=$ open to $9=$ dense.

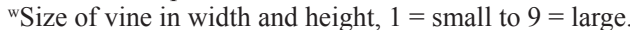

"Fruit firmness when machined harvested, $1=$ soft to $9=$ firm.

"Yield $=$ anticipated tons/acre, 1 to 3 below average, 4 to 6 average, 7 to 9 above average.

'Range of fruit maturity on plant, $1=$ fruit on all age to $9=$ all the fruit are similar maturity.

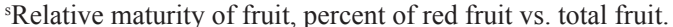

${ }^{\mathrm{r}}$ Least significant difference calculated by $t$ test using SAS program. 
Table 2. Test of horticultural quality characteristics performed by Campbell's Seeds in Woodland, Calif., 2000 of commercial controls and CULBPT-A46 and CULBPT-A48 lines

\begin{tabular}{|c|c|c|c|c|c|c|c|c|c|c|}
\hline Cultivar & $\begin{array}{c}\text { Fruit } \\
\text { crack }^{z}\end{array}$ & $\begin{array}{c}\text { Stems } \\
\text { adhere }^{\mathrm{y}}\end{array}$ & $\begin{array}{l}\text { Fruit } \\
\mathrm{wt} / \mathrm{g}\end{array}$ & $\begin{array}{c}\text { Total } \\
\text { yield } \\
\text { (tons/acre) }\end{array}$ & Maturity & $\begin{array}{l}\text { Color } \\
\mathrm{a} / \mathrm{b}^{\mathrm{w}}\end{array}$ & $\mathrm{TA}^{\mathrm{v}}$ & $\mathrm{pH}$ & $\mathrm{TS}^{\mathrm{u}}$ & NTSS \\
\hline CXD207 & 6.0 & 6.3 & 60.5 & 28.0 & 3.5 & 2.04 & 3.8 & 4.7 & 6.3 & 5.4 \\
\hline BOS3155 & 7.7 & 0.3 & 71.4 & 31.9 & 5.5 & 1.86 & 4.8 & 4.4 & 6.6 & 5.8 \\
\hline Hypeel45 & 6.7 & 1.0 & 64.8 & 21.6 & 2.0 & 1.89 & 5.4 & 4.4 & 7.1 & 6.3 \\
\hline Hypeel 303 & 8.0 & 0.0 & 70.2 & 27.9 & 6.0 & 1.91 & 4.3 & 4.5 & 6.4 & 5.6 \\
\hline CULBPT-A46-1 & 4.7 & 12.3 & 61.1 & 23.7 & 2.0 & 1.80 & 3.8 & 4.6 & 5.6 & 5.1 \\
\hline CULBPT-A46-2 & 5.7 & 12.3 & 48.4 & 22.2 & 3.0 & 1.91 & 4.8 & 4.5 & 7.7 & 6.8 \\
\hline CULBPT-A46-3 & 5.3 & 9.7 & 58.1 & 20.4 & 2.5 & 1.85 & 4.9 & 4.5 & 6.8 & 6.0 \\
\hline CULBPT-A48-1 & 6.3 & 1.0 & 68.4 & 20.1 & 7.5 & 1.79 & 5.6 & 4.4 & 6.7 & 5.9 \\
\hline CULBPT-A48-2 & 7.3 & 0.0 & 82.3 & 30.2 & 9.0 & 1.90 & 5.1 & 4.4 & 7.1 & 6.2 \\
\hline CULBPT-A48-3 & 7.7 & 0.3 & 75.1 & 25.6 & 8.0 & 1.88 & 5.3 & 4.4 & 6.6 & 5.7 \\
\hline CULBPT-A48-4 & 7.7 & 0.0 & 83.5 & 30.5 & 8.5 & 1.85 & 4.8 & 4.4 & 6.9 & 6.0 \\
\hline $\mathrm{LSD}^{\mathrm{s}}$ & 0.7 & 2.9 & 9.3 & 7.6 & 1.3 & 0.17 & 0.6 & 0.1 & 0.7 & 0.6 \\
\hline
\end{tabular}

${ }^{\mathrm{z}}$ Subjective score of number of cracked fruit, $1=$ a lot to about $9=$ no crack.

Number of fruit with stems attached in 25 random fruit.

${ }^{x}$ Relative maturity of fruit, 1 early to about 9 late.

${ }^{\mathrm{w}}$ Color measurement; ratio of $\mathrm{a} / \mathrm{b}$ with Hunter $\mathrm{a}$ and $\mathrm{b}$ scale, where $\mathrm{a}=$ red to green, red being higher positive values and green lower values and $\mathrm{b}=\mathrm{yellow}$ to blue, yellow being higher positive values and blue lower values.

${ }^{\mathrm{T}} \mathrm{TA}=$ titratable acidity.

uTS $=$ percent total solids.

${ }^{\mathrm{t}} \mathrm{NTSS}=$ nontitratible soluble solids, \%Brix.

${ }^{\mathrm{s}}$ Least significant difference calculated by $t$ test using SAS program.

and CULBPT-A48 lines to have slightly higher $\%$ Brix than cultivated controls. If this observation is confirmed in larger scale trials, the trait might have been transferred from the $S$. pimpinellifolium parent.

In summary, the CULBPT lines fulfill the goal of transferring late blight resistance to acceptable processing tomato inbred lines (Kim and Mutschler, 2005a, 2005b). The CULBPT-A46 and CULBPT-A48 lines performed similarly to commercial hybrids for most characteristics. The chief differences of some CULBPT-A46 lines from the control hybrids were the earlier maturity, and slightly smaller fruit of the CULBPT-A46 lines. The chief differences of some of the CULBPTA48 lines from the control hybrids were the later maturity, and slightly larger fruit of the CULBPT-A48 lines. The CULBPT-A48 lines are also jointless. The combination of the resistance to late blight in processing tomato lines with performance matching current processing tomatoes make these lines useful for developing either new lines or hybrids. The horticultural differences between the CULBPT-A46 and CULBPT-A48 lines provide the user greater flexibility in the choice of parents for crosses.

\section{Availability}

CULBPT-A46 and CULBPT-A48 lines are all breeding line releases. Requests for MTA form and seeds should be made to Martha Mutschler, Dept. of Plant Breeding and Genetics, Cornell University, Ithaca, NY 14853, or mam13@cornell.edu.

\section{Literature Cited}

Asian Vegetable Research and Development Center 1994. 1993 Progress report, p. 201-203. Asian Veg. Res. Dev. Ctr., Shanhua, Tainan, Taiwan.

Chunwongse, J., C. Chunwongse, L. Black, and P. Hanson. 2002. Molecular mapping of the $P h-3$ gene for late blight resistance in tomato. J. Hort. Sci. Biotechnol. 77:281-286.

Conover, R.A. and J.M. Walter. 1952. Heritability resistance to late blight of tomato. Phytopathology 42:197-199.

Conover, R.A. and J.M. Walter. 1953. The occurrence of a virulent race of Phytophthora infestans on late blight resistant tomato stocks. Phytopathology 43:344-345.

Fry, W.E. and S.B. Goodwin. 1997. Re-emergence of potato and tomato late blight in the United States. Plant Dis. 81:1349-1357.

Gallegly, M.E. 1952. Physiologic races of the tomato late blight fungus. Phytopathology 42:461-462.
Gallegly, M.E. 1960. Resistance to the late blight fungus in tomato, p. 113-135. In: Proceedings of the Plant Science Seminar. Campbell's Soup. Co., Camden, N.J.

Goodwin, S.B., L.S. Sujkowski, and W.E. Fry. 1995. Rapid evolution of pathogenicity within clonal lineages of the potato late blight disease fungus. Phytopathology 85:669-676.

Kawchuk, L.M., J. Hachey and D.R. Lynch. 1998. Development of sequence characterized DNA markers linked to a dominant Verticillium wilt resistance gene in tomato. Genome 41:91-95.

Kim, M.J. and M.A. Mutschler. 2005a. Characterization of late blight resistance derived from Solanum pimpinellifolium L3708 against multiple isolates of the pathogen, Phytophthora infestans. J. Amer. Soc. Hort. Sci. (in press).

Kim, M.J. and M.A. Mutschler. 2005b. Transfer to processing tomato and characterization of late blight resistance derived from S. pimpinellifolium L3708. J. Amer. Soc. Hort. Sci. (in press).

Peirce, L.C. 1970. A technique for screening tomato plants for single gene resistance to race O Phytophthora infestans. Plant Dis. Rptr. 54:681-682.

Peirce, L.C. 1971. Linkage tests with Ph conditioning resistance to race $\mathrm{O}$, Phytophthora infestans. Tomato Genet. Coop. Rpt. 21:30.

Peralta, I.E., S. Knapp, and D.M. Spooner 2005 New species of wild tomatoes (Solanum Section Lycopersicon: Solanaceae) from Northern Peru. Syst. Bot. 30:424-434 